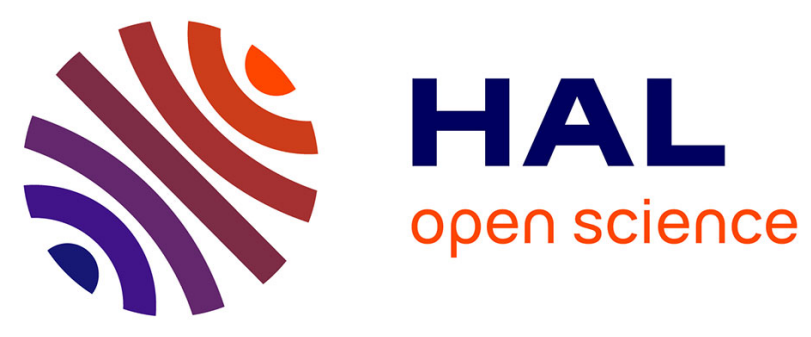

\title{
Fulminant giant-cell myocarditis on mechanical circulatory support: Management and outcomes of a French multicentre cohort
}

Santiago Montero, Nadia Aissaoui, Jean-Marc Tadié, Philippe Bizouarn, Vincent Scherrer, Romain Persichini, Clément Delmas, Florence Rolle, Emmanuel Besnier, Alexandre Le Guyader, et al.

\section{To cite this version:}

Santiago Montero, Nadia Aissaoui, Jean-Marc Tadié, Philippe Bizouarn, Vincent Scherrer, et al.. Fulminant giant-cell myocarditis on mechanical circulatory support: Management and outcomes of a French multicentre cohort. International Journal of Cardiology, 2018, 253, pp.105-112. 10.1016/j.ijcard.2017.10.053 . hal-01739721

\section{HAL Id: hal-01739721 \\ https://hal.sorbonne-universite.fr/hal-01739721}

Submitted on 21 Mar 2018

HAL is a multi-disciplinary open access archive for the deposit and dissemination of scientific research documents, whether they are published or not. The documents may come from teaching and research institutions in France or abroad, or from public or private research centers.
L'archive ouverte pluridisciplinaire HAL, est destinée au dépôt et à la diffusion de documents scientifiques de niveau recherche, publiés ou non, émanant des établissements d'enseignement et de recherche français ou étrangers, des laboratoires publics ou privés. 


\title{
Fulminant giant-cell myocarditis on mechanical circulatory support: management and outcomes of a French multicentre cohort
}

\author{
Santiago Montero ${ }^{1,9}$, Nadia Aissaoui ${ }^{2}$, Jean-Marc Tadié ${ }^{3}$, Philippe Bizouarn ${ }^{4}$, \\ Vincent Scherrer ${ }^{5}$, Romain Persichini ${ }^{6}$, Clément Delmas ${ }^{7}$, Florence Rolle ${ }^{8}$, \\ Emmanuel Besnier ${ }^{5}$, Alexandre Le Guyader ${ }^{8}$, Alain Combes ${ }^{1}$, and \\ Matthieu Schmidt ${ }^{1 *}$
}

\begin{abstract}
${ }^{1}$ Medical Intensive Care Unit, iCAN, Institute of Cardiometabolism and Nutrition, Hôpital de la PitiéSalpêtrière, Assistance Publique-Hôpitaux de Paris, Paris, ${ }^{2}$ Intensive Care Unit, U970, European Georges-Pompidou Hospital, Paris Descartes University, Paris, ${ }^{3}$ Infectious Diseases and Intensive Care Unit, Pontchaillou University Hospital, Rennes, France, ${ }^{4}$ Cardiac Intensive Care Department, CHU Nantes, Nantes, ${ }^{5}$ Rouen University Hospital, Department of Anaesthesiology and Critical Care, Rouen, ${ }^{6}$ Medical-Surgical Intensive Care Unit, CHU de La Réunion, Felix-Guyon Hospital, Saint Denis, La Réunion, France, ${ }^{7}$ Medical Intensive Care Unit, Rangueil Hospital, Toulouse, ${ }^{8}$ Thoracic and Cardiac Surgery Department, CHU Limoges, Limoges, France; and ${ }^{9}$ Acute and Intensive Cardiovascular Care Unit, Department of Cardiology, Hospital de la Santa Creu i Sant Pau, Biomedical Research Institute IIBSant Pau, Barcelona, Spain
\end{abstract}

\section{Text body word count : 2,995}

*Corresponding author: Service de Réanimation Médicale, iCAN, Institute of Cardiometabolism and Nutrition, Hôpital de la Pitié-Salpêtrière, 47, bd de l’Hôpital, 75651 Paris Cedex 13, France. Tel: +33 (0)142162937; Fax: +33 (0)142163817; e-mail: matthieu.schmidt@aphp.fr 


\section{Abstract (244 words)}

Aims: Giant-cell myocarditis (GCM) is a rare and often fatal form of myocarditis. Only a few reports have focused on fulminant forms. We describe the clinical characteristics, management and outcomes of GCM patients rescued by mechanical circulatory support (MCS).

Methods and results: The clinical features, diagnoses, treatments and outcomes of MCStreated patients in refractory cardiogenic shock secondary to fulminant GCM admitted to eight French intensive care units (2002-2016) were analysed. We also conducted a systematic review of this topic. Thirteen patients (median age 44 [range 21-76] years, Simplified Acute Physiology Score II 55 [40-79]) in severe cardiogenic shock (median [range] left ventricular ejection fraction 15\% [15-35\%] and blood lactate 4 [1-11] mmol/L) were placed on MCS 4 [0-28] days after hospital admission. Severe arrhythmic disturbances were frequent (77\%), with six (46\%) patients experiencing an electrical storm prior to MCS. Venoarterial extracorporeal membrane oxygenation was the first MCS option for 11 (85\%) patients. GCM was diagnosed in five (38\%) patients before transplant or death and treated with immunosuppressants; infections were the main complication (80\%). Four patients died on MCS and no patient presented long-term survival free from heart transplant (nine patients, 69\%). All transplanted patients were alive 1 year later and no GCM recurrence was reported after median follow-up of 42 [12145] months.

Conclusion: Outcomes of fulminant GCMs may differ from those of milder forms. In this context, heart transplant might likely be the only long-term survival option.

Keywords: Giant-cell myocarditis • Extracorporeal membrane oxygenation • Myocardial biopsy • Immunosuppressive therapy • Heart transplant 


\section{Introduction}

Giant-cell myocarditis (GCM) is a rare and often fatal form of myocarditis that mainly affects young healthy subjects with no prior co-morbidities [1]. The latest cardiac imaging techniques and proactive search with repeated biopsies recently highlighted this rare aetiology [2] that may have various clinical onset characteristics. Indeed, congestive heart failure, atrioventricular block, ventricular tachycardia (VT) or even acute myocardial infarction-mimicking syndromes have been described so far, with variable symptomonset-to-diagnosis intervals reported [1, 3]. In the 1990s, landmark studies aiming to report incidence, clinical presentations and outcomes of this rare disease were mostly conducted by the International Multicentre GCM Registry group [1, 4-7]. In their first report, nearly $90 \%$ of their patients were dead or transplanted 1 year after symptom onset [1]. More recent studies stressed the better outcomes obtained with combined immunosuppressants [2, 3]. However, the aforementioned cohorts did not specifically report the clinical course, management and outcomes of the most severe forms, namely fulminant myocarditis that rapidly required mechanical circulatory support (MCS). We describe, herein, a multicentre national experience with MCS-assisted fulminant GCM patients, and report their short- and long-term outcomes.

\section{Patients and Methods}

\subsection{Study population}

Eighteen French cardiac, surgical or medical intensive care units (ICUs) with a MCS program were contacted to participate in the study. Each ICU retrospectively analysed its database and that of their Pathology Laboratory to identify all patients with 1) confirmed GCM diagnosis and 2) MCS support (i.e., venoarterial extracorporeal membrane oxygenation [VA-ECMO] or another ventricular assist device [VAD]). Histology 
samples were obtained by endomyocardial biopsy (EMB), apical sample at LVAD implantation, explanted heart histology or autopsy. GCM diagnosis required myocardial histology confirmation showing multinucleated giant cells with or without myocyte necrosis, associated with an inflammatory infiltrate comprised of lymphocytes, histiocytes and eosinophils (Figure electronic supplemental material 1). The time of diagnosis was defined as the day the pathologist confirmed GCM in a myocardial sample. MCS indications were defined as acute-refractory cardiovascular failure, with evidence of tissue hypoxia (e.g., extensive skin mottling or elevated blood lactate) concomitant with adequate intravascular volume status; severely diminished right ventricular or left ventricular ejection fraction (LVEF); low cardiac index $\left(\leq 2.1 \mathrm{~L} / \mathrm{min} / \mathrm{m}^{2}\right)$; sustained hypotension despite high-dose catecholamine infusion (epinephrine $\geq 1 \mathrm{\gamma} / \mathrm{kg} / \mathrm{min}$ or dobutamine $\geq 10 \gamma / \mathrm{kg} / \mathrm{min}+$ norepinephrine $\geq 1 \mathrm{\gamma} / \mathrm{kg} / \mathrm{min}$ ); or refractory electrical storm [8]. MCS-exclusion criteria were malignancies with fatal prognosis within 5 years or irreversible neurological pathologies and decisions to limit therapeutic interventions. Trained cardiovascular surgeons surgically inserted VA-ECMO cannulas with femoralfemoral cannulation as previously described $[9,10]$. An additional $7 \mathrm{~F}$ catheter was systematically inserted into the femoral artery to prevent leg ischemia. Other MCSs used in our population were left ventricular assist device (LVAD), total artificial heart and biventricular MEDOS Assist System.

\subsection{Pre-MCS data collection}

At ICU admission, the following informations were collected for each patient: demographics (age, sex, body mass index), initial clinical characteristics and date of symptom onset. Admission disease-severity scores [Acute Physiology And Chronic Health Evaluation II (APACHE) [11], Simplified Acute Physiology Score (SAPS)II [12] 
and Sequential Organ Failure Assessment (SOFA) score [13]] were assessed during the first 24 hours of admission, trying to obtain the predicted mortality according to severity at ICU admission (see table ESM-1 in the supplemental material for further details on severity scores). During the pre-MCS period, the inotrope score was defined as dobutamine dose $(\gamma / \mathrm{kg} / \mathrm{min})+$ [norepinephrine dose $(\gamma / \mathrm{kg} / \mathrm{min})+$ epinephrine dose $(\gamma / \mathrm{kg} / \mathrm{min})] \times 100$ [14]. Severity of illness was assessed by the Interagency Registry for Mechanically Assisted Circulatory Support (INTERMACS) scale [15]. Thus, the occurrence of cardiac arrest, laboratory tests, blood-gas analyses, electrocardiogram and echocardiographic parameters (LVEF and left ventricular dilation) were collected.

\subsection{Outcome data}

The main prognostic variables included ECMO-weaning or heart transplant, immunosuppressant use and related infections, survival to hospital discharge, 90-day survival, 1-year survival post-transplant and long-term survival (evaluated in July 2017). We also recorded: the total number mechanical ventilation (MV) days; ventilatorassociated pneumonia (VAP); ICU and hospital lengths of stay; and in-ICU complications, e.g., severe haemorrhage, surgical wound or cannula infection, and requiring renal replacement therapy. Severe haemorrhage was considered life-threatening when intracerebral bleeding or haemorrhage resulting in substantial hemodynamic compromise required transfusion or increased vasopressor doses. In July 2017, survival and GCM-recurrence status were obtained for all survivors.

This investigation conforms with the principles outlined in the Declaration of Helsinki. In accordance with the ethical standards of our hospital's Institutional Review Board and French law, informed consent was not necessary for analyses of demographic, physiological and hospital-outcome data, because this retrospective observational study 
did not modify existing diagnostic or therapeutic strategies. The National Commission for Informatics and Liberties approved this study (no.1950673).

\subsection{Literature review}

We conducted a systematic MEDLINE-database literature review through the PubMed search engine with a global search strategy applying pre-specified selection with the terms "giant-cell myocarditis" or "giant-cell myocarditis" and "outcome”. Our query was restricted to controlled or observational studies (retrospective and prospective) and case series focused, exclusively, on prognosis of GCM with more than five patients published before August 2017.

\subsection{Statistical analyses}

Results were expressed as numbers (\%) or median [range]. Continuous variables were compared with Student's t-test or the Mann-Whitney $U$-test, as appropriate, whereas categorical variables were compared with $\chi^{2}$ tests. Analyses were computed using StatView v5.0 software (SAS Institute Inc., Cary, NC, USA) and a two-sided $P<0.05$ defined significance.

\section{Results}

\subsection{Study population}

During the 15-year study period (2002-2016), 13 patients (7 males; median age 44 [2176] years) from eight centres received MCS for fulminant GCM (Figure 1). Two patients were retrieved to the referral ECMO centre on VA-ECMO. ICU admission, median SAPS II and SOFA scores were high, respectively, 55 [40-79] and 10 [4-19]. Two (15\%) patients had pre-existing autoimmune disorders, i.e. hypothyroidism and vitiligo (Table 
1). Seven (54\%) patients were initially hospitalised for heart failure, while four (31\%) had arrhythmic disorders. Throughout the GCM course, arrhythmic disturbances were frequent, with 10 (77\%) patients having VT, ventricular fibrillation (VF), supraventricular arrhythmias or complete heart block. Six (46\%) patients experienced an electrical storm. The coronary angiograms available for 11 (85\%) patients were unremarkable.

VA-ECMO was the first MCS option for 11 (85\%) patients, one patient received a biventricular MEDOS Assist system in 2002 and another a HeartMate II LVAD for inotrope-dependent dilated cardiomyopathy. One patient was bridged from VA-ECMO to a total artificial heart. Five (38\%) patients suffered pre-ECMO cardiac arrest, with two (15\%) of them cannulated during cardiopulmonary resuscitation (CPR). INTERMACS status for 11 (85\%) patients was $\leq 2$ (Table 2). All patients required hemodynamic support with vasoactive drugs, resulting in a median inotrope score of 10 [3-523] $\gamma / \mathrm{kg} / \mathrm{min}$ at MCS cannulation. Pre-MCS median pH, blood lactate and LVEF were, respectively: 7.4 [7.0-7.6], 4 [1-11] and 15\% [10-35\%].

\subsection{GCM diagnosis and treatment}

Six (46\%) patients underwent pre-MCS magnetic resonance imaging that confirmed the myocarditis diagnosis. EMBs were obtained from five (38\%) patients: two of which were false-negatives. In addition, two other patients were diagnosed based on myocardial samples obtained during VAD implantation (i.e. total artificial heart and biventricular MEDOS Assist System). GCM-diagnosis confirmation was most frequently obtained by histological analysis of the explanted heart (Figure electronic supplemental material 2). Thus, only five (38\%) patients were diagnosed prior to death or transplant, with three of them receiving at least one immunosuppressant. In addition, two more patients, whose 
disease was highly suspected clinically, were also treated with immunosuppressant drugs. Various combinations of $\geq 2$ drugs were used, combining corticosteroids $(n=3)$, cyclosporine $(n=2)$, thymoglobulin $(n=2)$ or mycophenolate mofetil $(n=1)$ (more details about clinical characteristics, diagnostic approach and management of each patient can be found in Table 3). Among the five immunosuppressant-treated patients, four (80\%) developed nosocomial infections (i.e., VAP and/or cannula infection); one of them died of septic shock secondary to Clostridium difficile colitis and multiresistant Acinetobacter baumannii cannula infection. Notably, none of them achieved sufficient LVEF recovery to be weaned-off MCS. Moreover, it is worth noting that two patients received levosimendan, and three underwent VT-substrate ablation after an electrical storm, with no LVEF recovery, and VT subsequently recurred in all of them.

\subsection{Outcomes}

ECMO-related complications and outcomes according to 90-day status are reported in Table 2. As expected, 90-day survivors had significant lower disease-severity scores at ICU admission, without any significant differences in hemodynamic characteristics or cardiac function. Almost all patients experienced at least one major ECMO-related complication; eight (61\%) had severe haemorrhages and eight (61\%) received in-ICU renal replacement therapy, with no impact on 90-day survival. Compared with patients who died within 90 days, 90-day survivors had significantly lower bacteraemia $(P=0.02)$.

Four patients died within 90 days post-ICU admission, all on MCS (one of cardiac arrest-related multiorgan failure and three of refractory cardiogenic shock deemed ineligible for heart transplant). Notably, no patient cannulated during CPR survived to discharge (Table 1). Eight (89\%) of the nine 90-day survivors were transplanted and discharged after 8 [1-13] days on ECMO, 26 [9-75] in-ICU days and 66 [24-157] in- 
hospital days. The remaining survivor was initially implanted by LVAD while awaiting potential recovery that never occurred and he was transplanted 10 months after his first ICU admission. Pertinently, all 90-day survivors were alive 1-year post-transplant, with no patient admitted with heart failure nor presenting rejection $\geq 2 \mathrm{R}$ in the follow-up biopsies. Besides, unlike the high incidence recently reported by Elamm et al. [16], no early rejection was reported. In July 2017, long-term follow-up was 42 [12-145] months post-transplant. No patient has had documented GCM recurrence so far, and eight of the nine transplanted patients are still alive (July 2017). One patient died 9.5 years after heart transplant.

\subsection{Literature review}

In addition to our cohort study, eleven others including more than five GCM patients between 1984 and 2016 have been published to date (Table 4). Almost half of them came from the GCM Multicenter Registry, which published one of the first landmark studies on this entity. Initial arrhythmias were frequent (19-71\%), while lifetime diagnosis was obtained for $60-100 \%$ of the patients. The wide variability of patients' GCM severities yielded different mortality rates. However, cardiogenic shock at hospitalisation was frequently associated with death, transplantation or VAD, despite combined immunosuppressants.

\section{Discussion}

To our knowledge, this is the largest follow-up cohort study on life-threatening GCM with MCS in the modern era. Despite extreme disease severity at MCS implantation, frequent multiorgan failure and 57.5\% SAPS II-predicted mortality, 69\% of these patients 
were alive at 90 days. In fact, none recovered native heart function and all survivors were eventually transplanted despite immunosuppressants. Nevertheless, lifetime biopsies were diagnostic for only $38 \%$ of them.

Although poor prognosis has been continuously emphasised, with 42\% transplantfree-survival probability 5 years after symptom onset [2], outcomes of fulminant GCMs with refractory cardiogenic shock have been poorly described. Indeed, the literature on MCS-rescued severe GCM forms had been limited to small case series or case reports (Table 4) [5, 17-20]. For instance, only four (9\%) of 46 GCM patients received MCS in a recent study on long-term outcomes [2]. In accordance with several published case series [5, 17-19], none of our MCS-rescued patients recovered native heart function. However, it is worth noticing that few studies reported favourable outcome for fulminant GCM patients, including patients on MCS, with early aggressive immunosuppressant protocol [21-27].

Several factors could explain the lack of heart recovery in our extremely ill patients. First, the severity of GCM myocardial injury and, to a lesser degree, cardiac dysfunction at hospitalisation, constitute key predictors of transplant-free cardiac survival [2]. The median 4 [0-34] days from symptom onset to ICU admission was shorter for our cohort than previously reported (median 3 weeks) [1], which might reflect the former's more extensive myocardial necrosis and fibrosis [2]. Second, almost half of our patients experienced an electrical storm before MCS implantation, corroborating the strong impact of arrhythmias on prognosis in these severe GCMs. Recently, 22\% of a 51-patient GCM cohort had initial sustained VT or VF causing cardiac arrest, which markedly enhanced the risk of long-term life-threatening arrhythmias (up to 50\% at 5 years) [28]. In addition, the severity of myocardial damage at ECMO implantation, indicated by elevated creatine-kinase cardiac isoform or troponin-I concentrations (>12 mg/L), 
predicted unsuccessful weaning and fatal myocarditis [10]. Similar findings were also reported for GCM [2]. However, a recent and smaller study on MCS-assisted GCMs failed to demonstrate the predictive performance of cardiac troponin levels [18]. Lastly, although EMB is considered the gold-standard diagnostic tool, only 5 (38\%) of our cohort patients underwent this procedure, so lack of GCM confirmation have surely limited immunosuppressant initiation in more patients.

Although most of our patients fulfilled the current recommended criteria to perform EMB in the acute heart failure setting [29], EMB was mostly underused in our cohort. Similarly, in a recent Italian cohort of 57 ECMO-treated fulminant myocarditis patients, only $26 \%$ of them had EMB-proven myocarditis [30]. EMB's low negative-predictive value has been reported frequently [30-32]. For GCM patients, EMB sensitivity may change throughout the disease course as endocardial inflammation progresses. Indeed, first-EMB sensitivity for our patients reached 60\%. When GCM is strongly suspected clinically, a second EMB may be indicated because its sensitivity improved to 93\% [3]. Moreover, magnetic resonance imaging-guided [33] or systematic left ventricular biopsies [34-36] could further enhance EMB sensitivity.

Rapidly progressive myocardial necrosis with rapid onset of heart failure (lasting $<1$ month) requires prompt diagnosis and aggressive treatment in most patients to contain this overwhelming process. The results of several studies, which frequently excluded severe and fulminant GCMs because they were diagnosed at the time of transplant, LVAD implantation or death, highlighted a potential benefit of combined immunosuppressants. In the landmark study by Cooper et al., combined immunosuppressants significantly prolonged the time to death or transplant from 3.0 to 12.3 months [1]. In 2008, the same author's team reported that the combination of high-dose steroids, cyclosporine and muromonab-CD3 for 4 weeks limited the extent of necrosis, cellular inflammation and 
giant cells in biopsies, with unclear impact on prognosis [4]. In a recent study aimed at assessing the prognosis of fulminant myocarditis, Ammirati et al. [27] showed dismal outcome for 6 patients with fulminant GCM and MCS, with half of them treated with immunosuppressants. One died, and only one other survived without heart transplant. On the other hand, Suarez-Barrientos et al. [26] recently reported left ventricular recovery in 6 patients with cardiogenic shock, including 3 patients with MCS, after combined immunosuppressant therapy with high-dose steroids and rabbit anti-thymocyte globulin. Although this promising treatment regimen has been also reported in other case reports [21-25], larger studies on the benefit of antibodies against T-cell populations in this context are still warranted.

Early diagnosis and prompt aggressive immunosuppressant initiation are both of major importance. Indeed, in a Finnish cohort, 1-year transplant-free survival reached 69\% after combined immunosuppressants [3], and 5-year transplant-free survival rose from $42 \%$ to 48\% when GCM had been diagnosed by lifetime biopsies and specific treatment initiated [2]. However, such intense immunosuppression exposes patients to infectious complications. For instance, half of a 26 patients cohort treated with a cyclosporine-based regimen developed a nosocomial infection [6]. Similarly, $80 \%$ of our immunosuppressant-treated patients experienced $\geq 1$ infections while on MCS (i.e., VAP and/or cannula infection. Notwithstanding, combined immunosuppression should be the gold-standard treatment in GCM patients. An exhaustive search for infections should be performed while immunosuppressants are given. If case of no rapid improvement on VAECMO after a treatment with combine immunosuppressant treatment, including highdose steroids, thymoglobulin and cyclosporine, heart transplant seems urgently warranted [18-20]. Importantly, at 1-year post-transplantation, all transplanted patients were alive and GCM had not recurred after 42 (12-145) months of follow-up. However, among the 
largest series, GCM-recurrence rates in allografts ranged from $6 \%$ to $25 \%$ after different follow-up durations [1-3]. Moreover, the impact of immunosuppressant in pre-transplant to prevent GCM recurrence remains unknown.

The main strengths of our study are the number of patients, the detailed characterization of their fulminant GCMs on MCS and their long post-transplant followup. However, our study also has several limitations. First, although a multicentre cohort was necessary to gather patients with this rare disease, the small size of our population remains its main drawback. Ten centres looked back at their databases without finding any case of GCM, which could be explained by differences in digitalization of medical charts and difficulty to found past cases. Furthermore, worldwide studies focusing on MCS-treated GCM patients are needed to confirm our findings [37]. Second, only a limited number of patients were diagnosed and given immunosuppressants before death or transplantation. This inhomogeneous treatment management does not allow to confirm the absence of immunosuppressant benefit in that severe population. However, it illustrates the complicated management of these severely ill patients, for whom EMB may lead to significant complications while on MCS. Third, the surgical implantation of VAECMO in our patients may increase the risk of cannulas-related infections. Further studies with percutaneous approach are needed to better define the impact of this issue in GCM patients treated with immunosuppressants. Lastly, our study covered a 15-year period with different MCS types and new-generation ECMO devices used more recently. Therefore, we cannot exclude changes of global MCS management for refractory cardiogenic shock throughout the study period. However, most of our patients received VA-ECMO support, now widely available in tertiary-care centres.

\section{Conclusions}


Predicting the likelihood of native cardiac recovery or dismal outcome of patients with fulminant GCM is of utmost importance, particularly for resource allocation and planning more definitive treatments. Our findings highlight that outcomes of severe GCMs may have different features compared to milder forms. In this context, heart transplantation appears associated with good long-term survival, although the risk of long-term GCM recurrence has been reported. Immunosuppressants, including high-dose steroids, rabbit anti-thymocyte globulin and cyclosporine, should be initiated, although their benefit remains unclear in MCS-treated fulminant GCM patients. A worldwide cohort of fulminant GCM patients is urgently needed to assess the optimal management of this population.

\section{Acknowledgements}

The authors thank the medical and nursing staffs of the eight centres participating in the study. The authors would also like to thank Dr. Mario San Martín-Alonso for his valuable contribution to figure design and description of the histological findings.

\section{Funding}

S.M. is funded by a 2016 Clinical Training Grant awarded by the European Society of Cardiology.

\section{Conflicts of interest}

None declared.

\section{Supplemental material}

Supplementary data to this article can be found online at XXXXX 


\section{References}

[1] L. T. J. Cooper, G. J. Berry, R. Shabetai, Idiopathic Giant-Cell Myocarditis - Natural History and Treatment, N Engl J Med 336 (1997) 1860-6.

[2] K. Ekstrom, J. Lehtonen, R. Kandolin, A. Raisanen-Sokolowski, K. Salmenkivi, M. Kupari, Long-term outcome and its predictors in giant cell myocarditis, Eur J Heart Fail 18 (2016) 14528.

[3] R. Kandolin, J. Lehtonen, K. Salmenkivi, A. Raisanen-Sokolowski, J. Lommi, M. Kupari, Diagnosis, treatment, and outcome of giant-cell myocarditis in the era of combined immunosuppression, Circ Heart Fail 6 (2013) 15-22.

[4] L. T. J. Cooper, J. M. Hare, H. D. Tazelaar, et al., Usefulness of immunosuppression for giant cell myocarditis, Am J Cardiol 102 (2008) 1535-9.

[5] R. A. Davies, J. P. Veinot, S. Smith, C. Struthers, P. Hendry, R. Masters, Giant cell myocarditis: clinical presentation, bridge to transplantation with mechanical circulatory support, and long-term outcome, J Heart Lung Transplant 21 (2002) 674-9.

[6] J. J. Maleszewski, V. M. Orellana, D. O. Hodge, U. Kuhl, H. P. Schultheiss, L. T. J. Cooper, Long-term risk of recurrence, morbidity and mortality in giant cell myocarditis, Am J Cardiol $115(2015)$ 1733-8.

[7] R. Davidoff, I. Palacios, J. Southern, J. T. Fallon, J. Newell, G. W. Dec, Giant cell versus lymphocytic myocarditis. A comparison of their clinical features and long-term outcomes, Circulation 83 (1991) 953-61.

[8] P. Ponikowski, A. A. Voors, S. D. Anker, et al., 2016 ESC Guidelines for the diagnosis and treatment of acute and chronic heart failure: The Task Force for the diagnosis and treatment of acute and chronic heart failure of the European Society of Cardiology (ESC)Developed with the special contribution of the Heart Failure Association (HFA) of the ESC, Eur Heart J 37 (2016) 2129-200. 
[9] A. Combes, P. Leprince, C. E. Luyt, et al., Outcomes and long-term quality-of-life of patients supported by extracorporeal membrane oxygenation for refractory cardiogenic shock, Crit Care Med 36 (2008) 1404-11.

[10] M. Mirabel, C. E. Luyt, P. Leprince, et al., Outcomes, long-term quality of life, and psychologic assessment of fulminant myocarditis patients rescued by mechanical circulatory support, Crit Care Med 39 (2011) 1029-35.

[11] W. A. Knaus, E. A. Draper, D. P. Wagner, J. E. Zimmerman, APACHE II: a severity of disease classification system, Crit Care Med 13 (1985) 818-29.

[12] J. R. Le Gall, S. Lemeshow, F. Saulnier, A new Simplified Acute Physiology Score (SAPS II) based on a European/North American multicenter study, Jama 270 (1993) 2957-63. [13] J. L. Vincent, R. Moreno, J. Takala, et al., The SOFA (Sepsis-related Organ Failure Assessment) score to describe organ dysfunction/failure. On behalf of the Working Group on Sepsis-Related Problems of the European Society of Intensive Care Medicine, Intensive Care Med 22 (1996) 707-10.

[14] G. Wernovsky, D. Wypij, R. A. Jonas, et al., Postoperative course and hemodynamic profile after the arterial switch operation in neonates and infants. A comparison of low-flow cardiopulmonary bypass and circulatory arrest, Circulation 92 (1995) 2226-35.

[15] L. W. Stevenson, F. D. Pagani, J. B. Young, et al., INTERMACS profiles of advanced heart failure: the current picture, J Heart Lung Transplant 28 (2009) 535-41.

[16] C. A. Elamm, S. G. Al-Kindi, C. M. Bianco, B. P. Dhakal, G. H. Oliveira, Heart Transplantation in Giant Cell Myocarditis: Analysis of the United Network for Organ Sharing Registry, J Card Fail 23 (2017) 566-9.

[17] E. S. Brilakis, L. J. Olson, G. J. Berry, et al., Survival outcomes of patients with giant cell myocarditis bridged by ventricular assist devices, Asaio j 46 (2000) 569-72. 
[18] N. A. Gilotra, N. Minkove, M. K. Bennett, et al., Lack of Relationship Between Serum Cardiac Troponin I Level and Giant Cell Myocarditis Diagnosis and Outcomes, J Card Fail 22 (2016) 583-5.

[19] L. K. Murray, J. Gonzalez-Costello, S. N. Jonas, et al., Ventricular assist device support as a bridge to heart transplantation in patients with giant cell myocarditis, Eur J Heart Fail 14 (2012) $312-8$.

[20] J. Seeburger, N. Doll, S. Doll, M. A. Borger, F. W. Mohr, Mechanical assist and transplantation for treatment of giant cell myocarditis, Can J Cardiol 26 (2010) 96-7. [21] E. Ammirati, F. Oliva, O. Belli, et al., Giant cell myocarditis successfully treated with antithymocyte globuline and extracorporeal membrane oxygenation for 21 days, J Cardiovasc Med (Hagerstown) (2015).

[22] D. Steinhaus, E. Gelfand, P. A. VanderLaan, R. D. Kociol, Recovery of giant-cell myocarditis using combined cytolytic immunosuppression and mechanical circulatory support, J Heart Lung Transplant 33 (2014) 769-71.

[23] H. J. Ankersmit, R. Ullrich, B. Moser, et al., Recovery from giant cell myocarditis with ECMO support and utilisation of polyclonal antithymocyte globulin: a case report, Thorac Cardiovasc Surg 54 (2006) 278-80.

[24] U. Grabmaier, C. Brenner, H. Methe, et al., An alternative immunosuppressive regimen to prolong transplant free survival in a patient with giant cell myocarditis, Int J Cardiol 168 (2013) e27-8.

[25] L. J. Pinderski, G. C. Fonarow, M. Hamilton, et al., Giant cell myocarditis in a young man responsive to T-lymphocyte cytolytic therapy, J Heart Lung Transplant 21 (2002) 818-21. [26] A. Suarez-Barrientos, J. Wong, A. Bell, H. Lyster, G. Karagiannis, N. R. Banner, Usefulness of Rabbit Anti-thymocyte Globulin in Patients With Giant Cell Myocarditis, Am J Cardiol 116 (2015) 447-51. 
[27] E. Ammirati, M. Cipriani, M. Lilliu, et al., Survival and Left Ventricular Function Changes in Fulminant Versus Nonfulminant Acute Myocarditis, Circulation 136 (2017) 529-45.

[28] K. Ekstrom, J. Lehtonen, R. Kandolin, A. Raisanen-Sokolowski, K. Salmenkivi, M. Kupari, Incidence, Risk Factors, and Outcome of Life-Threatening Ventricular Arrhythmias in Giant Cell Myocarditis, Circ Arrhythm Electrophysiol 9 (2016).

[29] L. T. J. Cooper, K. L. Baughman, A. M. Feldman, et al., The role of endomyocardial biopsy in the management of cardiovascular disease: a scientific statement from the American Heart Association, the American College of Cardiology, and the European Society of Cardiology, Circulation 116 (2007) 2216-33.

[30] R. Lorusso, P. Centofanti, S. Gelsomino, et al., Venoarterial Extracorporeal Membrane Oxygenation for Acute Fulminant Myocarditis in Adult Patients: A 5-Year Multi-Institutional Experience, Ann Thorac Surg 101 (2016) 919-26.

[31] A. L. Caforio, S. Pankuweit, E. Arbustini, et al., Current state of knowledge on aetiology, diagnosis, management, and therapy of myocarditis: a position statement of the European Society of Cardiology Working Group on Myocardial and Pericardial Diseases, Eur Heart J 34 (2013) 2636-48, 48a-48d.

[32] B. Maisch, V. Ruppert, S. Pankuweit, Management of fulminant myocarditis: a diagnosis in search of its etiology but with therapeutic options, Curr Heart Fail Rep 11 (2014) 166-77. [33] R. C. Shields, H. D. Tazelaar, G. J. Berry, L. T. J. Cooper, The role of right ventricular endomyocardial biopsy for idiopathic giant cell myocarditis, J Card Fail 8 (2002) 74-8.

[34] C. Chimenti, A. Frustaci, Contribution and risks of left ventricular endomyocardial biopsy in patients with cardiomyopathies: a retrospective study over a 28-year period, Circulation 128 (2013) 1531-41.

[35] A. Kalra, R. Kneeland, M. A. Samara, L. T. J. Cooper, The Changing Role for Endomyocardial Biopsy in the Diagnosis of Giant-Cell Myocarditis, Cardiol Ther 3 (2014) 53-9. 
[36] A. Yilmaz, I. Kindermann, M. Kindermann, et al., Comparative evaluation of left and right ventricular endomyocardial biopsy: differences in complication rate and diagnostic performance, Circulation 122 (2010) 900-9.

[37] M. Noutsias, C. Tschope, Giant cell myocarditis: still a conundrum. The need for a worldwide registry, Eur J Heart Fail 18 (2016) 1459-61. 


\section{Figure legends}

Figure 1 Flow chart. GCM, giant-cell myocarditis; VA-ECMO, venoarterial extracorporeal membrane oxygenation; VAD, ventricular assist device. 
Table 1 Clinical characteristics of the 13 cohort patients at the time of MCS implantation

\begin{tabular}{|c|c|}
\hline Variable & Values \\
\hline Male & $7(54)$ \\
\hline Age, years & $44[21-76]$ \\
\hline Body mass index, $\mathrm{kg} / \mathrm{m}^{2}$ & $23[20-36]$ \\
\hline SOFA score & $12[6-18]$ \\
\hline \multicolumn{2}{|l|}{ Cardiovascular risk factors } \\
\hline Hypertension & $3(23)$ \\
\hline Active smoking & $4(44)$ \\
\hline Autoimmune disorders & $2(15)$ \\
\hline Days from onset to first hospital admission & $4[0-34]$ \\
\hline \multicolumn{2}{|l|}{ Clinical manifestation } \\
\hline Congestive heart failure & $7(54)$ \\
\hline Chest pain & $2(15)$ \\
\hline Arrhythmia symptoms* & $4(31)$ \\
\hline Rhythm and conduction disturbances ${ }^{\dagger}$ & $10(77)$ \\
\hline Complete atrioventricular heart block & $4(31)$ \\
\hline Ventricular tachycardia & $6(46)$ \\
\hline Electrical storm pre-MCS & $6(46)$ \\
\hline Co-existing atrioventricular block \& ven & $2(15)$ \\
\hline \multicolumn{2}{|l|}{ Tachycardia } \\
\hline \multicolumn{2}{|l|}{ Type of MCS } \\
\hline Venoarterial ECMO & $11(85)$ \\
\hline Left ventricular assist device & $1(8)$ \\
\hline Biventricular MEDOS & $1(8)$ \\
\hline
\end{tabular}

Values for categorical variables are expressed as $n(\%)$ and continuous variables as median [range], unless stated otherwise.

SOFA, Sequential Organ Failure Assessment; MCS, mechanical circulatory support; ECMO, Extracorporeal Membrane Oxygenation.

*Palpitations, syncope or dizziness.

${ }^{\dagger}$ Advanced atrioventricular block, ventricular tachycardia, ventricular fibrillation or supraventricular arrhythmia. 
Table 2. Hemodynamic status, ICU events and outcomes of MCS-treated giant-cell myocarditis patients according to 90-day survival status

\begin{tabular}{|c|c|c|c|c|}
\hline Event/outcome & $\begin{array}{l}\text { All patients } \\
(n=13)\end{array}$ & $\begin{array}{l}\text { Survivors } \\
(n=9)\end{array}$ & $\begin{array}{l}\text { Non-survivors } \\
(n=4)\end{array}$ & $P$ value \\
\hline \multicolumn{5}{|l|}{ At ICU admission } \\
\hline APACHE II & 13 [4-37] & 9 [4-37] & $29[21-30]$ & 0.08 \\
\hline SAPS II & 55 [40-79] & $46[40-68]$ & 76 [67-79] & 0.03 \\
\hline SOFA score & 10 [4-19] & $8[4-18]$ & 12 [12-19] & 0.02 \\
\hline \multicolumn{5}{|l|}{ INTERMACS } \\
\hline INTERMACS 1 & $5(38)$ & $2(22)$ & $3(75)$ & 0.22 \\
\hline INTERMACS 2 & $6(46)$ & $5(55)$ & $1(25)$ & 0.56 \\
\hline INTERMACS 3 & $2(15)$ & $2(22)$ & $0(0)$ & 0.99 \\
\hline $\begin{array}{l}\text { Hospital admission-to-MCS interval, } \\
\text { days }\end{array}$ & $4[0-28]$ & $6[0-28]$ & $2.5[0-7]$ & 0.31 \\
\hline Cardiac arrest before MCS & $5(38)$ & $3(33)$ & $2(50)$ & 0.99 \\
\hline \multicolumn{5}{|l|}{ At MCS cannulation } \\
\hline ECMO-CPR & $2(15)$ & $0(0)$ & $2(50)$ & 0.08 \\
\hline Heart rate, bpm & $118[0-140]$ & 116 [42-140] & $120[0-125]$ & 0.90 \\
\hline Inotrope score, $\gamma / \mathrm{kg} / \mathrm{min}$ & $10[3-523]$ & 15 [5-323] & 10 [3-523] & 0.76 \\
\hline $\mathrm{pH}$ & $7.4[7.0-7.6]$ & $7.4[7.0-7.6]$ & $7.4[7.2-7.5]$ & 0.99 \\
\hline Blood lactate, mmol/L & $4[1-11]$ & 5 [3-9] & $3[1-11]$ & 0.23 \\
\hline Natremia, mmol/L & 130 [125-142] & 127 [125-139] & 138 [133-142] & 0.04 \\
\hline Creatinine, $\mu \mathrm{mol} / \mathrm{L}$ & 106 [68-409] & 106 [68-409] & 108 [80-154] & 0.80 \\
\hline AST, U/L & 62 [22-288] & 48 [22-288] & 66 [60-108] & 0.27 \\
\hline Haemoglobin, g/L & 121 [95-48] & 126 [95-148] & 120 [112-141] & 0.64 \\
\hline QRS duration, msec & 126 [84-204] & 140 [93-160] & 100 [84-204] & 0.46 \\
\hline Right bundle-branch block & $3(23)$ & $2(22)$ & $1(25)$ & 0.99 \\
\hline Left ventricular dilatation & $5(38)$ & $5(55)$ & $0(0)$ & 0.10 \\
\hline LVEF at implantation, \% & 15 [10-35] & 15 [10-30] & 20 [10-35] & 0.24 \\
\hline In-ICU complications & & & & \\
\hline
\end{tabular}




\begin{tabular}{lllll}
\hline Bacteraemia & $6(46)$ & $2(22)$ & $4(100)$ & 0.02 \\
VAP & $6(46)$ & $5(55)$ & $1(25)$ & 0.56 \\
Severe haemorrhage & $8(61)$ & $4(44)$ & $4(100)$ & 0.10 \\
Renal replacement therapy & $8(61)$ & $4(44)$ & $4(100)$ & 0.10 \\
ECMO duration, days & $10[1-33]$ & $8[1-23]$ & $17[8-33]$ & 0.15 \\
MV duration, days & $9[1-28]$ & $3[1-21]$ & $16[8-28]$ & 0.09 \\
ICU LOS, days & $21[8-75]$ & $26[9-75]$ & $16[8-33]$ & 0.17 \\
Hospital LOS, days & $40[12-157]$ & $66[24-157]$ & $16[12-40]$ & 0.02 \\
\hline
\end{tabular}

Values for categorical variables are expressed as $n(\%)$ and continuous variables as median [range], unless stated otherwise.

APACHE II, Acute Physiology And Chronic Health Evaluation II; ICU, intensive care unit; SAPS II, Simplified Acute Physiology Score II; SOFA, Sequential Organ-Failure Assessment; INTERMACS, Interagency Registry for Mechanically Assisted Circulatory Support” scale; MCS, mechanical circulatory support; CPR, cardiopulmonary resuscitation; bpm, beats per minute; AST, aspartate aminotransferase; LVEF, left ventricular ejection fraction; VAP, ventilator-associated pneumonia; ECMO, extracorporeal membrane oxygenation; MV, mechanical ventilation; LOS, length of stay. 
Table 3: Details about clinical characteristics, diagnostic approach, management and outcome of each patient. 


\begin{tabular}{|c|c|c|c|c|c|c|c|c|c|c|c|c|c|c|c|c|c|c|c|c|}
\hline Cha & Gender & Age & Year & $\begin{array}{c}\text { Initial } \\
\text { symptoms }\end{array}$ & $\begin{array}{l}\text { Time from first } \\
\text { hospital admission to } \\
\text { diagnosis }\end{array}$ & $\begin{array}{l}\text { Time from symptoms' } \\
\text { onset to diagnosis }\end{array}$ & $\begin{array}{l}\text { Time from symptoms' } \\
\text { onset to Mcs }\end{array}$ & $\begin{array}{l}\text { Arrhythmic } \\
\text { issue }\end{array}$ & INTERMACS & $\begin{array}{l}\text { LVEF pre- } \\
\text { ECMO }\end{array}$ & ЕмB & $\begin{array}{l}\text { Way of } \\
\text { diagnosis }\end{array}$ & $\begin{array}{l}\text { Type of } \\
\text { Mcs }\end{array}$ & $\begin{array}{c}\text { Days on VA } \\
\text { ECMO }\end{array}$ & Immunosuppressants & Transplant & LVAD & $\begin{array}{l}\text { 90-day } \\
\text { survivor }\end{array}$ & $\begin{array}{l}\text { 1-year } \\
\text { survivor }\end{array}$ & $\begin{array}{c}\text { Years of } \\
\text { follow up } \\
\text { after } \\
\text { transplant }\end{array}$ \\
\hline 1 & Female & 53 & 2015 & AS & 23 & 26 & 10 & $\mathrm{VT}, \mathrm{CAVB}$ & 1 & 55 & + & Biopsy & VA ECMO & 33 & & & - & - & 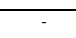 & NA \\
\hline 2 & Female & 31 & 2013 & CHF & 11 & 145 & 135 & None & 2 & 15 & - & $\begin{array}{c}\text { Explanted } \\
\text { heart }\end{array}$ & VA ECMO & 10 & - & + & - & + & + & 3,4 \\
\hline 3 & Female & 61 & 2015 & CHF & 0 & 5 & 5 & VT & 1 & 35 & + & Biopsy & VA ECMO & 17 & $\begin{array}{l}\text { Steroids, cyclosporine, } \\
\text { thymoglobulin }\end{array}$ & - & - & - & - & NA \\
\hline 4 & Male & 41 & 2014 & AS & 25 & 25 & 21 & CAVB & 3 & 10 & + & Biopsy & VA ECMO & 23 & $\begin{array}{l}\text { Steroids, cyclosporine, } \\
\text { MMF, thymoglobulin }\end{array}$ & + & - & + & + & 2,2 \\
\hline 5 & Female & 28 & 2008 & AS & 34 & 43 & 37 & $\mathrm{VT}, \mathrm{CAVB}$ & 1 & 25 & $\cdot$ & $\begin{array}{c}\text { Explanted } \\
\text { heart }\end{array}$ & VA ECMO & 6 & - & + & - & + & + & 8,5 \\
\hline 6 & Male & 76 & 2009 & CHF & 12 & 21 & 13 & AF, flutter & 2 & 10 & - & Autopsy & VA ECMO & 8 & Steroids & - & - & - & - & $\mathrm{NA}$ \\
\hline 7 & Male & 22 & 2006 & CHF & 3 & 7 & 6 & VF & 2 & 12 & - & $\begin{array}{c}\text { Explanted } \\
\text { heart }\end{array}$ & VA ECMO & 1 & - & + & - & + & + & 9,5 \\
\hline 8 & Male & 44 & 2012 & CHF & 311 & NR & NR & None & 3 & 15 & - & $\begin{array}{c}\text { Explanted } \\
\text { heart }\end{array}$ & $\begin{array}{c}\text { LVAD - HM } \\
\|\end{array}$ & NA & - & + & + & + & + & 3,8 \\
\hline 9 & Male & 21 & 2002 & $C P$ & 1 & 4 & 4 & CAVB & 1 & 20 & - & Apical samplet & Biv MEDOS & $N A$ & - & - & + & - & - & NA \\
\hline 10 & Male & 44 & 2014 & $\mathrm{CHF}$ & 20 & 54 & 40 & vT & 2 & 20 & - & Apical sample ${ }^{\dagger}$ & $\begin{array}{l}\text { VA ECMO / } \\
\text { TAH }\end{array}$ & 14 & Steroids & + & + & + & + & 2,1 \\
\hline 11 & Male & 44 & 2005 & $\mathrm{CHF}$ & 4 & NR & NR & None & 2 & 10 & + & $\begin{array}{c}\text { Explanted } \\
\text { heart }\end{array}$ & VA ECMO & 4 & - & + & - & + & + & 11,9 \\
\hline 12 & Female & 31 & 2016 & $C P$ & 20 & 897 & 889 & VT & 2 & 30 & + & $\begin{array}{c}\text { Explanted } \\
\text { heart }\end{array}$ & VA ECMO & 6 & Steroids & + & - & + & + & 0,8 \\
\hline 13 & Female & 55 & 2016 & AS & 26 & 176 & 151 & VT & 1 & 15 & - & $\begin{array}{c}\text { Explanted } \\
\text { heart }\end{array}$ & VA ECMO & 12 & - & + & - & + & + & 0,6 \\
\hline \multicolumn{21}{|c|}{ PATIENTS NOT ASIISTED WITH MCS } \\
\hline 14 & Female & 52 & 2010 & CHF & NR & NR & NA & None & 3 & 20 & - & $\begin{array}{c}\text { Explanted } \\
\text { heart }\end{array}$ & NA & NA & . & + & - & + & - & 3 \\
\hline 15 & Male & 54 & 2013 & CHF & $N R$ & $N R$ & NA & None & 3 & 25 & - & $\begin{array}{c}\text { Explanted } \\
\text { heart }\end{array}$ & NA & NA & - & + & - & NR & NR & 0,25 \\
\hline
\end{tabular}

AS, arrhythmic symptoms*; CHF, congestive heart failure; CP, chest pain. VT, ventricular tachycardia; CAVB: complete atrioventricular heart block; AF: atrial fibrillation; VF, ventricular fibrillation; INTERMACS, "Interagency Registry for Mechanically Assisted Circulatory Support” scale; LVEF, left ventricular ejection fraction; EMB, endomyocardial biopsy; MCS, mechanical circulatory support; VA ECMO, Venoarterial extracorporeal membrane oxygenation; HM II, HeartMate II; TAH, total artificial heart; MMF, mycophenolate mofetil; LVAD, left ventricular assist device. NA, Not applicable. NR, Not reported.

*Palpitations, syncope or dizziness. ${ }^{\dagger}$ Apical sample obtained at LVAD implantation 
Table 4: Giant-cell myocarditis series with more than 5 patients included in the systematic review

\begin{tabular}{|c|c|c|c|c|c|c|c|c|c|c|c|c|}
\hline \multirow[t]{2}{*}{ Reference } & \multirow{2}{*}{$\begin{array}{l}\text { Inclusion } \\
\text { dates }\end{array}$} & \multirow{2}{*}{$\begin{array}{c}\text { Patients, } \\
\mathrm{n}\end{array}$} & \multirow{2}{*}{$\begin{array}{l}\text { Arrhythmia at } \\
\text { admission (\%) }\end{array}$} & \multirow{2}{*}{$\begin{array}{c}\text { Lifetime } \\
\text { diagnosis* } \\
(\%)\end{array}$} & \multirow[t]{2}{*}{ CS (\%) } & \multirow[t]{2}{*}{ LVEF (\%) } & \multirow{2}{*}{$\begin{array}{l}\text { LVAD } \\
(\%)\end{array}$} & \multirow{2}{*}{$\begin{array}{c}\text { ECMO } \\
(\%)\end{array}$} & \multirow{2}{*}{$\begin{array}{c}\text { Transplanted } \\
\text { (\%) }\end{array}$} & \multirow{2}{*}{$\begin{array}{l}\text { Combined } \\
\text { ISs† }(\%)\end{array}$} & \multicolumn{2}{|c|}{ Outcome (\%) } \\
\hline & & & & & & & & & & & Overall survival & Transplant-free survival \\
\hline Cooper et al.[1] & 1995-1997 & 63 & 19 & 60 & NR & - & 8 & - & 54 & 35 & $\begin{array}{l}\text { No IS; average survival } 3.0 \text { months without } \\
\mathrm{OHT} \text {; } \\
\text { combined IS; average survival } 12.3 \text { months } \\
\text { or } \mathrm{OHT}\end{array}$ & $\mathrm{NA}$ \\
\hline Cooper et al.[4] & $1999-2005$ & 11 & - & 100 & 27 & $44 \pm 18$ & 0 & 0 & 18 & 100 & NA & 72\% alive without transplant at 1 year \\
\hline Murray et al.[19] & $2000-2010$ & 6 & 67 & - & 100 & $13 \pm 8$ & 100 & 0 & 67 & 50 & $\begin{array}{l}100 \% \text { survival after } 5.7 \pm 4.1 \text { years post- } \\
\text { OHT }\end{array}$ & $\mathrm{NA}$ \\
\hline Davies et al.[5] & 1984-2002 & 7 & 71 & 0 & 86 & - & 57 & 0 & 100 & 0 & $86 \%$ alive after $44 \pm 34$ months post-OHT & $\mathrm{NA}$ \\
\hline Brilakis et al.[17] & GCM MR & 9 & - & - & - & - & 100 & - & 78 & - & $\begin{array}{l}\text { 29\% 1-year post-OHT survival of previously } \\
\text { VAD-supported patients }\end{array}$ & $\mathrm{NA}$ \\
\hline $\begin{array}{l}\text { Maleszewski et } \\
\text { al.[6] }\end{array}$ & GCM MR & 26 & - & 100 & - & - & 4 & - & 19 & 96 & $\begin{array}{l}88 \% \text { overall survival after } 4.8(1-16.6) \text { years } \\
\text { of follow-up starting 1-year post-diagnosis }\end{array}$ & $\begin{array}{l}72 \% \text { of survival free from transplantation at } \\
5 \text { years of follow-up }\end{array}$ \\
\hline Gilotra et al.[18] & - & 6 & 50 (overall) & 67 & 83 & $15 \pm 9$ & 83 & 0 & 33 & 17 & $33 \%$ survival at index hospitalisation & $\begin{array}{l}16 \% \text { survival free from death or } \\
\text { transplantation at index hospitalisation }\end{array}$ \\
\hline Kandolin et al.[3] & 1991-2011 & 32 & 56 & 81 & - & $38 \pm 13$ & 3 & 0 & 31 & 81 & $\begin{array}{l}85 \% \text { overall survival after a median follow-up } \\
\text { of } 14.5 \text { months [0.3-90 months] }\end{array}$ & $\begin{array}{l}69 \% \text { and } 52 \% \text { transplant-free survival rates } \\
\text { at 1- \& 5-year, respectively, post-symptom } \\
\text { onset after combined IS }\end{array}$ \\
\hline Ekström et al.[2] & 1991-2015 & 46 & 48 & 83 & - & $41 \pm 15$ & 4 & 4 & 39 & $70 \ddagger$ & $\begin{array}{l}80 \% \text { and } 58 \% \text { global survival rates at } 1 \& 5 \\
\text { years, respectively. }\end{array}$ & $\begin{array}{l}65 \% \text { and } 42 \% \text { transplant-free survival at } 1 \& \\
5 \text { years, respectively, after symptom onset }\end{array}$ \\
\hline
\end{tabular}




\begin{tabular}{|c|c|c|c|c|c|c|c|c|c|c|c|c|}
\hline $\begin{array}{l}\text { Suárez-Barrientos } \\
\text { et al.[26] }\end{array}$ & 2008-2012 & 6 & 33 & 100 & 83 & 20 & 33 & 17 & 33 & 100 & $67 \%$ global survival at 1-year & $\begin{array}{l}50 \% \text { survival free from death or } \\
\text { transplantation at 1-year after combined ISs } \\
\text { (rATG and steroids). }\end{array}$ \\
\hline Ammirati et al. [27] & $2001-2016$ & 6 & NR & NR & 100 & $22(12-35)$ & 17 & 83 & 67 & 50 & $83 \%$ survival at hospital discharge & $\begin{array}{l}17 \% \text { survival free from death or } \\
\text { transplantation at hospital discharge }\end{array}$ \\
\hline This study & $2002-2016$ & 13 & 31 & 38 & 100 & $15(10-35)$ & 23 & 84 & 69 & 15 & $\begin{array}{l}69 \% \text { survival at 90-days \& 1-year post- } \\
\text { symptom onset }\end{array}$ & $\begin{array}{l}0 \% \text { survival free from transplantation at } 1 \\
\text { year after symptom onset }\end{array}$ \\
\hline
\end{tabular}

*Diagnosed before death or transplantation, either by endomyocardial biopsy or by examination of apical samples obtained at ventricular assist device implantation.

†Immunosuppressant regimen consisting of 2 or more agents before transplant.

$\ddagger$ Patients treated with triple combination therapy.

CS, cardiogenic shock; LVEF, left ventricular ejection fraction; LVAD, left ventricular assist device; ECMO, extracorporeal membrane oxygenation; IS, immunosuppressant; NR, not reported;

NA, not applicable; OHT, orthotopic heart transplant; GCM MR, giant-cell myocarditis multicenter registry; rATG, rabbit anti-thymocyte globulin. 


\section{Online supplement}

Fulminant giant-cell myocarditis on mechanical circulatory support: management and outcomes of a French multicentre cohort

Santiago Montero ${ }^{1,9}$, Nadia Aissaoui², Jean-Marc Tadié3 ${ }^{3}$ Philippe Bizouarn4, Vincent Scherrer ${ }^{5}$, Romain Persichini ${ }^{6}$, Clément Delmas ${ }^{7}$, Florence Rolle ${ }^{8}$, Emmanuel Besnier ${ }^{5}$, Alexandre Le Guyader ${ }^{8}$, Alain Combes ${ }^{1}$, and

Matthieu Schmidt ${ }^{1 *}$ 
Table 1 : Severity scores at ICU admission

\begin{tabular}{|c|c|c|c|c|c|c|}
\hline & Year & Journal & $\begin{array}{l}\text { Number } \\
\text { of } \\
\text { patients }\end{array}$ & Variables included & Aims and comments & Limitations \\
\hline SAPS II & 1993 & JAMA & 13152 & $\begin{array}{l}12 \text { physiology variables, age, type of admission } \\
\text { (scheduled surgical, unscheduled surgical, or } \\
\text { medical), and three underlying disease variables } \\
\text { (acquired immunodeficiency syndrome, } \\
\text { metastatic cancer, and hematologic malignancy). }\end{array}$ & $\begin{array}{l}\text { Based on a large international sample of } \\
\text { patients, the score provides an estimate } \\
\text { risk of death regardless of the primary } \\
\text { diagnosis at admission. }\end{array}$ & $\begin{array}{l}\text { Burn patients, coronary care patients and cardiac } \\
\text { surgery patients were excluded in the initial study. }\end{array}$ \\
\hline SOFA & 1996 & $\begin{array}{l}\text { Intensive } \\
\text { Care Med }\end{array}$ & 1643 & $\begin{array}{l}\text { Evaluation of separated organ dysfunction, } \\
\text { assigning } 1 \text { to } 4 \text { points to each of the following } \\
\text { systems: respiratory, circulatory, renal, } \\
\text { haematology, hepatic and central nervous system. }\end{array}$ & $\begin{array}{l}\text { To objectively and quantitatively describe } \\
\text { the degree of organ dysfunction over time } \\
\text { and to evaluate morbidity in intensive care } \\
\text { unit (ICU) septic patients. }\end{array}$ & $\begin{array}{l}\text { SOFA was initially designed not to predict outcome } \\
\text { but to describe a sequence of complications in the } \\
\text { critically ill. Since its introduction the SOFA score } \\
\text { has also been used for predicting mortality, although } \\
\text { it was not developed to this purpose. }\end{array}$ \\
\hline APACHE II & 1985 & $\begin{array}{ll}\text { Crit } & \text { Care } \\
\text { Med }\end{array}$ & 5815 & $\begin{array}{l}\text { The score consisted of three parts: } 12 \text { acute } \\
\text { physiological parameters, patient's age and } \\
\text { chronic diseases and surgical procedures. The data } \\
\text { for measurements are gathered within the first } 24 \\
\text { h of intensive care unit stay, choosing the farthest } \\
\text { result from baseline for the final calculations. }\end{array}$ & $\begin{array}{l}\text { APACHE II allows the probability of } \\
\text { death before discharge from hospital to be } \\
\text { estimated. It has been considered the gold- } \\
\text { standard in intensive therapy for years. } \\
\text { Subsequent versions have been developed } \\
\text { every few years, but APACHE II remains } \\
\text { to be used in practice }\end{array}$ & $\begin{array}{l}\text { APACHE II score was not validated to be used to } \\
\text { evaluate patients }<16 \text { years of age, those who are } \\
\text { hospitalised in the ICU }<8 \mathrm{~h} \text {, those who have burns } \\
\text { or those who underwent coronary bypass grafting. } \\
\text { Moreover, database cohorts did not include patients } \\
\text { who were readmitted to the ICU during the same } \\
\text { hospitalisation. }\end{array}$ \\
\hline
\end{tabular}


Figure ESM-1 Histological samples of giant-cell myocarditis (haematoxylin and eosin staining. (A) Fibroconnective tissue, without preserved myocardium, showing multinucleated giant cells (black arrows) and a diffuse infiltrate of lymphocytes, histiocytes and plasmacytoid cells. An asteroid body is seen (asterisk). No well-formed granulomas are seen (20×). (B) Higher magnification (40×) showing a giant cell, lymphocytes (dotted line), histiocytes (dashed black arrow) and plasmacytoid cells (white arrow).

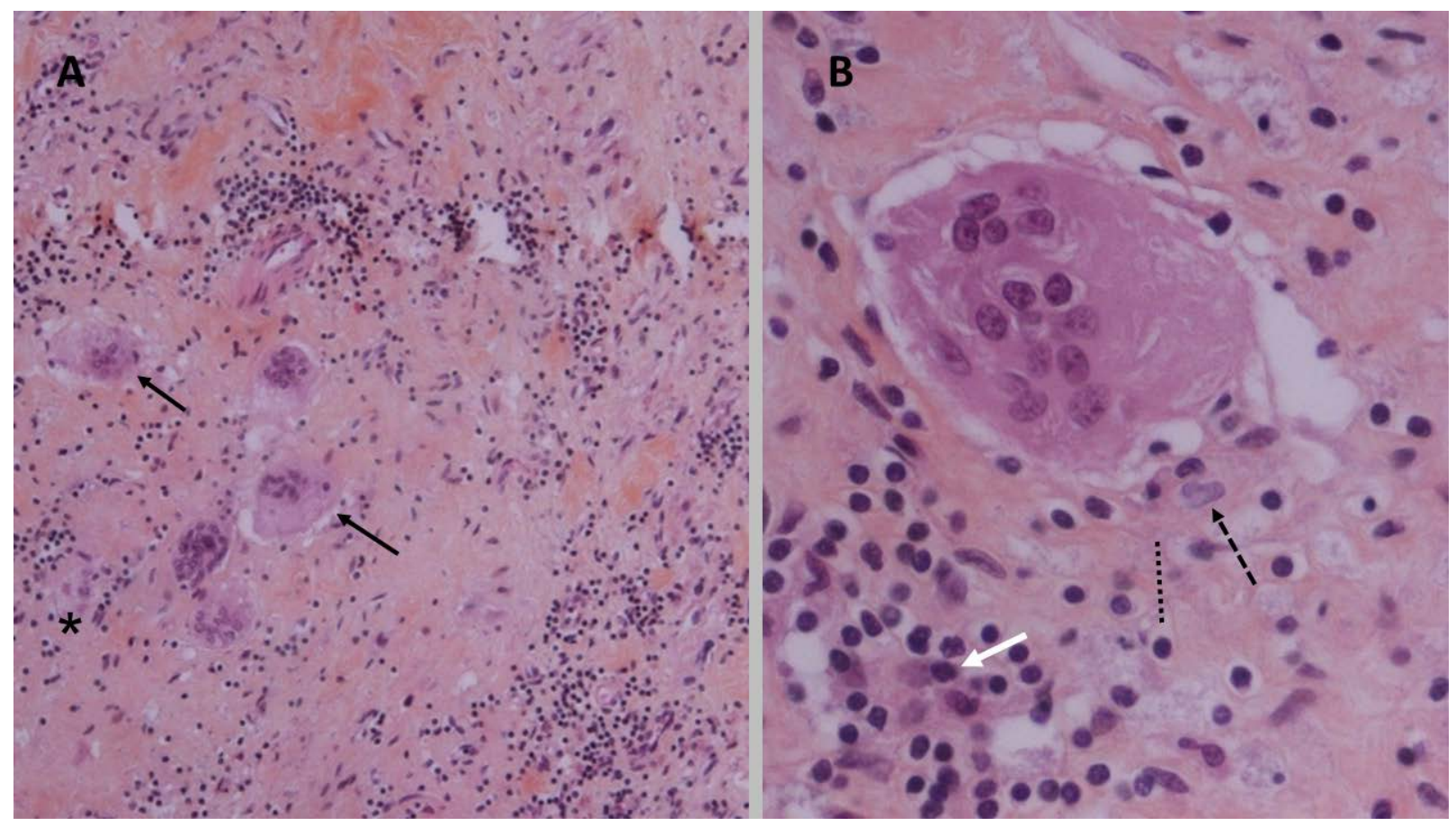


Figure ESM-2 Giant-cell myocarditis diagnosis. VAD, ventricular assist device.

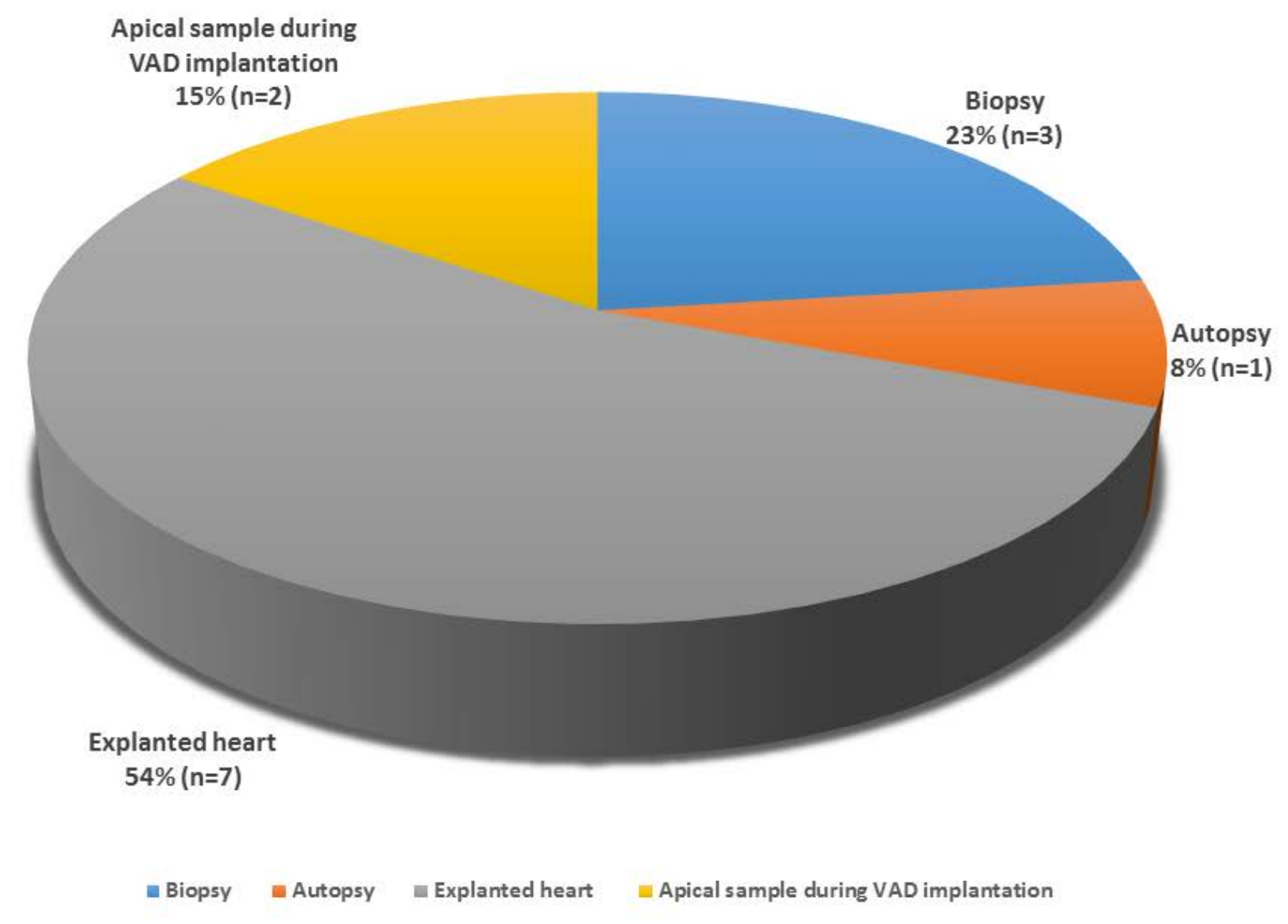

